\section{Respon Gender Maskulin dan Feminin terhadap Video yang Diunggah Akun Instagram @d_kadoor}

Fatihatus Syahida

Mahasiswa Pascasarjana Prodi Linguistik UGM Surel:fsyahida1@gmail.com

INTISARI

Instagram merupakan salah satu media sosial yang menjadi favorit masyarakat untuk mengekspresikan dirinya. Dari situ muncul bentuk-bentuk tuturan baru, bahkan satu kata bisa menunjukkan ekspresi yang bertolak belakang. Misalnya, kata anjing merupakan bentuk umpatan, tetapi dalam kolom komentar di instagram@d_kadoor, kata tersebut digunakan bukan sebagai umpatan, tetapi juga tidak sepenuhnya bermakna positif. Gender maskulin dan feminin pun mengekspresikan tuturannya dengan cara yang berbeda. Penelitian ini bertujuan untuk (1) menganalisis perbedaan bentuk respons gender maskulin dan feminin terhadap video yang diunggah akun instagram@d_kadoor dan (2) menganalisis perbedaan karakteristik tuturan gender maskulin dan feminin dalam merespons video yang diunggah akun instagram @,d_kadoor. Jenis penelitian ini adalah deskriptif kualitatif. Data dalam penelitian ini berupa tuturan di kolom komentar instagram@d_kadoor yang diambil secara purposive sampling, yaitu dengan mengambil sampel yang sesuai dengan tujuan penelitian. Data diperoleh dengan metode simak bebas libat cakap. Analisis data dilakukan dengan menggunakan metode padan pragmatis dan translasional dengan teknik hubung banding menyamakan (HBS) dan teknik hubung banding memperbedakan (HBB) serta metode agih dengan teknik baca markah. Dari 32 data yang diperoleh, 10 data dituturkan oleh gender maskulin, sedangkan 22 data lainnya dituturkan oleh feminin. Bentuk respons gender maskulin dan feminin terhadap video yang diunggah akun instagram @d_kadoor terdiri atas pujian, sindiran, umpatan, dan bentuk lain yang tidak teridentifikasi. Perbedaan karakteristik tuturan gender maskulin dan feminin dikelompokkan berdasarkan pilihan kata, unsur suprasegmental, dan emotikon yang digunakan

Kata kunci: bahasa dan gender; bentuk respons; pilihan kata; unsur suprasegmental; emotikon

\title{
PENDAHULUAN
}

Adanya kebebasan berpendapat mendorong masyarakat untuk mengekspresikan diri dengan leluasa. Sebagai konsekuensinya, muncul bentuk-bentuk bahasa baru untuk mewakili ekspresiekspresi yang dirasa belum cukup terwadahi dengan kosakata yang telah ada. Perkembangan teknologi pun mendorong bentuk-bentuk bahasa baru tersebut menyebar dengan pesat, salah satunya melalui media sosial. Instagram merupakan salah satu media sosial yang menjadi favorit masyarakat untuk mengekspresikan dirinya. Di Indonesia, instagram telah digunakan oleh 45 juta orang. Dengan angka ini, Indonesia menjadi pengguna instagram terbesar se-Asia Pasifik (Bohang, 2017). Masyarakat menggunakannya untuk menunjukkan aktivitasnya, mempromosikan bisnisnya, mengungkapkan kebahagiaannya dan/atau kesedihannya, dan lain-lain. Setiap orang pun bebas berkomentar di sana. Karena itulah, tuturan-tuturan di instagram dapat mencerminkan realitas bahasa yang terjadi di masyarakat.

Bahasa memiliki beragam fungsi, salah satunya adalah untuk mengekspresikan perasaan. Bahasa seperti ini berbeda dengan bahasa ilmiah. Kridalaksana (1985: 5I) menyebutnya sebagai bahasa emotif. Bahasa ini diidentikkan dengan penggunaan kata afektif yang mempunyai gaya atau makna yang menunjukkan perasaan (KBBI), baik perasaan ketika mengagumi, memuji, membenci, terkejut, sakit hati, atau yang lainnya. Fungsi afektif dari bahasa terkait dengan siapa yang "berhak/boleh" mengatakan apa yang erat sekali hubungannya dengan kekuasaan dan status sosial (Thomas dan Wareing, 2007: 14).

Perasaan-perasaan tersebut diekspresikan dengan bahasa yang berbeda, tetapi bisa juga satu kata digunakan untuk menunjukkan ekspresi yang bertolak belakang. Misalnya, dalam penelitian yang dilakukan oleh Putra (20l3), ditemukan bahwa kata anjing merupakan bentuk umpatan. Namun, 
dalam kolom komentar di instagram @d_kadoor, kata tersebut digunakan bukan sebagai umpatan, tetapi juga tidak sepenuhnya bermakna positif. Pemilik akun @d_kadoor adalah seorang selebgram (selebritas yang terkenal melalui instagram) yang berasal dari Malang, Jawa Timur. Kadoor (@d_kadoor) dalam kehidupan sehari-harinya bertindak sesuai kodratnya sebagai laki-laki, tetapi saat menjalankan profesinya sebagai selebgram, dia bertindak layaknya perempuan. Video-video unggahannya pun menuai banyak komentar, baik yang berupa pujian, sindiran, maupun yang lainnya. Pengategorian bentuk respons tersebut dianalisis berdasarkan kategori kata yang menyusun tuturan tersebut, antara lain verba, adjektiva, adverbia, dan interjeksi.

Komentar yang dituturkan laki-laki (maskulin) dan perempuan (feminin) pun memiliki perbedaan. Dalam kajian sosiolinguistik, gender dibedakan dengan seks. Seks didasarkan pada sifat biologis seorang individu, sedangkan gender didasarkan pada konstruksi sosial yang tidak ada hubungannya dengan sifat biologis (Milroy \& Gordon, 2003: 100). Gender maskulin dan feminin memperbedakan dirinya dalam berbahasa. Lakoff (1973:49) menyatakan bahwa bahasa perempuan menunjukkan perbedaan dalam pilihan leksikal, frekuensi penggunaan, intonasi, dan unsur suprasegmental lainnya.

Perbedaan tuturan maskulin dan feminin dapat dilihat dari unsur suprasegmenal yang digunakan. Unsur suprasegmental adalah unsur kebahasaan yang tidak dapat dipenggal-penggal. Unsur suprasegmental ini meliputi (I) tekanan (stress), yaitu keras lemahnya pengucapan satuan kebahasaan; (2) nada (tone), yaitu tinggi rendahnya pengucapan kebahasaan; (3) durasi (duration), yaitu panjang dan pendeknya pengucapan satuan kebahasaan; dan (4) jeda (juncture), yaitu perhentian (jarak waktu ujar antara satuan lingual yang satu dengan yang lain). Kombinasi antara tekanan, nada, durasi, dan jeda disebut intonasi (Wijana, 2009: 29-30). Dalam bahasa tulis, unsur suprasegmental tersebut dapat dilihat dari pengulangan fonem, baik vokal maupun konsonan.

Selain itu, perbedaan tersebut dapat dilihat dari ekspresial verbal visual yang berupa emotikon. Emotikon adalah ilustrasi, ikon, atau kelompok karakter pada papan tombol yang menunjukkan ekspresi wajah, sikap, atau emosi, biasa digunakan dalam komunikasi elektronik, media sosial, dan sebagainya (KBBI, 20 I8). Ada banyak bentuk emotikon yang tersedia di aplikasi sosial media, salah satunya instagram. Berikut ini dipaparkan beberapa emotikon yang sering digunakan oleh pengguna media sosial, sebagaimana disebutkan oleh (Herian, 2017).

Tabel 1. Emotikon dan Fungsi/Maknanya

\begin{tabular}{|c|c|c|c|}
\hline No & $\begin{array}{l}\text { Penyebutan } \\
\text { Emotikon }\end{array}$ & Wujud & Fungsi/ Makna \\
\hline 1 & Bahagia & & Mengekspresikan rasa bahagia \\
\hline 2 & Gugup & & Mengekspresikan rasa gugup \\
\hline 3 & Tertarik & & Menunjukkan rasa tertarik \\
\hline 4 & $\begin{array}{l}\text { Tertawa Sambil } \\
\text { Menangis }\end{array}$ & & $\begin{array}{l}\text { Merespons momen-momen yang sangat } \\
\text { menggembirakan }\end{array}$ \\
\hline 5 & $\begin{array}{l}\text { Bahagia Dengan } \\
\text { Mata Tersenyum }\end{array}$ & & Menunjukkan rasa bahagia yang lebih banyak \\
\hline 6 & $\begin{array}{l}\text { Tertawa Sampai } \\
\text { Berkeringat }\end{array}$ & & $\begin{array}{l}\text { Seperti halnya tertawa sampai berkeringat dalam } \\
\text { kehidupan nyata }\end{array}$ \\
\hline 7 & Tertawa & & $\begin{array}{l}\text { Mengekspresikan tertawa yang tidak berlebihan } \\
\text { dan juga tidak terlalu memaksa }\end{array}$ \\
\hline 8 & Muka Memerah & & $\begin{array}{l}\text { Digunakan untuk berbicara dengan seseorang yang } \\
\text { special }\end{array}$ \\
\hline 9 & $\begin{array}{l}\text { Memberikan } \\
\text { Ciuman }\end{array}$ & & $\begin{array}{l}\text { Menunjukkan ekspresi rasa suka tanpa } \\
\text { menimbulkan efek yang berlebihan }\end{array}$ \\
\hline 10 & Jatuh Cinta & 20 & Menunjukkan sesuatu yang sangat disukai \\
\hline 11 & Tepuk Tangan & & Menyampaikan rasa bangga terhadap sesuatu \\
\hline
\end{tabular}


Penelitian ini bertujuan untuk (I) menganalisis perbedaan bentuk respons gender maskulin dan feminin terhadap video yang diunggah akun instagram @d_kadoor dan (2) menganalisis perbedaan karakteristik tuturan gender maskulin dan feminin dalam merespons video yang diunggah akun instagram @d_kadoor.

Jenis penelitian ini adalah deskriptif kualitatif karena bertujuan untuk mendeskripsikan fenomena bahasa yang terjadi. Penelitian ini mendeskripsikan bentuk-bentuk respons serta perbedaan karakteristik tuturan maskulin dan feminin dalam mengomentari video yang diunggah di akun instagram @d_kadoor. Data dalam penelitian ini berupa tuturan di kolom komentar instagram @d_kadoor. Sumber data dalam penelitian ini adalah kolom komentar akun instagram @d_kadoor. Data dalam penelitian ini diambil secara purposive sampling, yaitu dengan mengambil sampel yang sesuai dengan tujuan penelitian. Tuturan diambil dari kolom komentar terhadap video yang diunggah oleh @d_kadoor dengan caption “I kata untuk jogetan yayuk...?? (emotikon) ampun gak kalian kalau di giniin.. ? (emotikon)". Data diperoleh dengan metode simak bebas libat cakap (Mahsun, 20 I2: 243). Peneliti menangkap layar komentar-komentar di akun instagram @d_kadoor kemudian mencatat data tersebut di lembar penyimakan. Pada tahap analisis data, peneliti terlebih dahulu melakukan klasifikasi tuturan-tuturan berdasarkan tujuan tuturan tersebut dan identitas gender penutur serta memberikan kode data. Rumusan masalah pertama dianalisis dengan metode padan pragmatis (Sudaryanto, 2015: 18) dan metode padan translasional (Sudaryanto, 2015: 17) dengan teknik hubung banding menyamakan (HBS), teknik hubung banding memperbedakan (HBB) (Sudaryanto, 20I5: 32). Sementara itu, rumusan masalah kedua dianalisis dengan metode agih (Sudaryanto, 20I5: I8) dengan teknik baca markah (Sudaryanto, 2015: 129).

\section{PEMBAHASAN}

\section{PERBEDAAN BENTUK RESPONS GENDER MASKULIN DAN FEMININ TERHADAP VIDEO YANG DIUNGGAH AKUN INSTAGRAM @D_KADOOR}

Dari 32 data yang diperoleh, 10 data dituturkan oleh gender maskulin, sedangkan 22 data lainnya dituturkan oleh feminin. Hal ini membuktikan pernyataan Thomas dan Wareing (2007: I30) bahwa perempuan lebih aktif dalam mengomentari topik-topik personal, seperti keluarga, perasaan, dan persahabatan mereka. Video yang diunggah akun instagram @d_kadoor ini termasuk dalam kategori tersebut, yaitu berkaitan dengan perasaan yang menghibur. Bentuk respons gender maskulin dan feminin terhadap video yang diunggah akun instagram @d_kadoor terdiri atas pujian, sindiran, umpatan dan bentuk lain yang tidak teridentifikasi.

\section{a. Bentuk Pujian}

Data dikelompokkan sebagai bentuk pujian karena tuturan ini berfungsi untuk mengapresiasi tindakan mengagumkan yang dilakukan oleh @d_kadoor. Terdapat 20 data yang termasuk dalam bentuk pujian, yaitu I 5 dituturkan oleh feminin dan 5 dituturkan oleh maskulin. Tuturan gender feminin lebih kompleks daripada tuturan gender maskulin. Gender feminin bisa menggabungkan adjektiva, adverbia, interjeksi, onomatope tertawa, dan emotikon dalam satu tuturan, misalnya data (OI) berikut ini.

(01) Lincah bgt sihhh haha $\quad$ (emotikon love warna kuning)

$$
\text { adj adv intrj onomatope emotikon }
$$

Sementara itu, gender maskulin hanya menggunakan adjektif dan emotikon (02) atau adjektif dan adverbia (03) dalam satu tuturan.

(02) Jago (emotikon tertawa sambil menangis)

$$
\text { adj emotikon }
$$


(03) Lemes banget

adj adv

Bentuk pujian ini ditandai dengan adanya adjektiva bermakna positif yang menyifati hal-hal yang mengacu pada @d_kadoor. Adjektiva yang dituturkan oleh gender feminin adalah lincah, asik, keren, mantap, syahdu, luwes. Sementara itu, adjektiva yang dituturkan oleh gender maskulin adalah jago dan amazing 'menakjubkan' yang berasal dari bahasa Inggris. Ada juga adjektiva yang dituturkan oleh gender maskulin dan juga feminin, yaitu lemes. Ada satu bentuk yang unik, yaitu cetar. Jika dilihat dari KBBI, tidak ditemukan kata cetar, tetapi yang ada adalah cetar-ceter (nomina) 'tiruan bunyi cambuk yang dilecutkan berkali-kali'. Sementara itu, jika ditinjau dari kategorinya, kata cetar pada tuturan tersebut memenuhi persyaratan sebagai adjektiva, yaitu bisa didampingi kata-kata seperti lebih, sangat, dan agak (Kridalaksana, I 986 dalam Ramlan, 1991: 48). Kata cetar dituturkan oleh gender maskulin dan feminin. Adjektiva tersebut juga dapat diikuti dengan interjeksi yang menjadikan tingkat bentuk pujian itu menjadi naik, seperti berikut ini.

(04) $\underline{\text { Cetar }} \underline{\text { dah }}$ pokoke adj intr nom

Selain dibentuk dari adjektiva, bentuk pujian dapat diungkapkan menggunakan verba, seperti ngakak dan kekel 'tertawa terbahak-bahak'. Verba tersebut menggambarkan ekspresi penutur yang terhibur dengan goyangan @d_kadoor. Secara tidak langsung, verba tersebut mewakili bentuk pujian pada umumnya yang menggunakan adjektiva, seperti lucu dan keren.

\section{b. Bentuk Sindiran}

Bentuk sindiran hanya satu kali dituturkan oleh gender maskulin. Data dikelompokkan sebagai bentuk sindiran karena tuturan ini bertujuan untuk menyindir atau mengejek secara tidak langsung. Sindiran dibentuk dari leksikon yang berkonotasi negatif, seperti bokong 'pantat' yang mengacu pada bagian tubuh yang tabu untuk dibahas dan kesetrum 'tersetrum' yang merupakan suatu kejadian menyedihkan yang tidak diinginkan. Hal itu dapat dilihat pada tuturan (05) berikut ini.

(05) Kui bokong kesetrum apa pye ya 'itu pantat tersetrum apa bagaimana ya'

Hal itu berbeda dengan adanya kata bokong pada tuturan (06) dan kesetrum pada tuturan (07) berikut ini.

(06) Haha kok iso yo bokonge kyok ngunu (4 emotikon tertawa sambil menangis) ngakak gett @d_kador

(07) Kesetrum (emotikon tertawa)/ / Tp keren mbak (emotikon memberikan ciuman)

Tuturan (06) dan (07) tersebut tidak dikategorikan sebagai sindiran, tetapi menjadi bentuk pujian karena disertai dengan adanya emotikon dan kata lainnya yang bermaka pujian, yaitu ngakak (06) dan keren (07).

\section{c. Bentuk Umpatan}

Bentuk umpatan hanya dituturkan oleh gender maskulin sebanyak 2 orang. Umpatan adalah kata-kata yang dianggap tidak sopan ketika diucapkan (Crystal, 1995: I72). Kata umpatan yang dituturkan adalah asyu dan jancuk. Asyu berasal dari kata asu 'anjing' (Jawa).

\section{d. Bentuk Tidak Teridentifikasi}

Bentuk tidak teridentifikasi dituturkan oleh 7 gender feminin dan 2 gender feminin. Dikatakan sebagai bentuk yang tidak teridentifikasi karena tuturan tersebut menggunakan pilihan leksikal yang biasanya digunakan untuk mengumpat, seperti njir dan anjir yang berasal dari kata anjing; syem yang berasal dari asem (penghalusan dari bentuk asu); bajirut yang berasal dari bajingan; cuk, jancok, wendel yang berasal dari endel 'genit'; dan bangke yang berasal dari kata bangkai. 
Namun, terdapat unsur pendukung lainnya yang menyebabkan tuturan tersebut tidak dapat dikategorikan sebagai makian, misalnya dengan adanya emotikon dan onomatope tertawa, seperti wkwkwk dan hahaha. Hal itu dapat dilihat pada tuturan berikut ini.

(08) Anjir beeee ini orang masih ada aja (2 emotikon tertawa sambil menangis)

(09) Syem (2 emotikon tertawa sambil menangis)

(10)Bajirutthahaha@firdadinika@dlistyani@dindazafira

(11) Jancok temen, hhha

(12) Wendel (emotikon tertawa sambil menangis)

Kata anjir (08) dan syem (09) yang biasanya digunakan untuk mengumpat tidak menjadikan tuturan tersebut menjadi bentuk umpatan atau makian karena adanya emotikon tertawa sambil menangis yang menunjukkan ekspresi kebahagiaan. Begitu pula kata bajirutt (I0) dan jancok (II) tidak menjadi bentuk umpatan atau makian karena adanya kata hhha yang merepresentasikan tertawa bahagia. Kata wendel (I2) yang biasanya digunakan untuk mencela/ memaki menjadi tidak bermakna demikian karena adanya emotikon tertawa. Perpaduan antara kata yang bermakna negatif dengan ekspresi yang menunjukkan hal positif tersebut menyebabkan bentuk tuturannya sulit diidentifikasi secara jelas.

\section{PERBEDAAN KARAKTERISTIK TUTURAN GENDER MASKULIN DAN FEMININ DALAM MERESPONS VIDEO YANG DIUNGGAH AKUN INSTAGRAM @D_KADOOR}

Perbedaan karakteristik tuturan gender maskulin dan feminin dikelompokkan berdasarkan pilihan kata, unsur suprasegmental, dan emotikon yang digunakan.

\section{a. Pilihan kata}

Pilihan kata yang digunakan berkategori adjektiva, interjeksi, dan nomina. Adjektiva yang digunakan oleh gender maskulin adalah jago, lemes, amazing 'menakjubkan', dan jancok. Dalam konteks lainnya, jancok termasuk kategori interjeksi, tetapi juga dapat menjadi adjektiva karena dilekati dengan adverbia temen 'sangat/ sekali' seperti pada tuturan berikut ini.

(05) Jancok temen, hhha

Sementara itu, adjektiva yang digunakan oleh gender feminin adalah keren, mantap, luwes, bohay, bajirut 'bajingan', wendel (endel) 'genit', emeiiiiyiiiiinngg (amazing) 'menakjubkan', dan syahdu. Dari beberapa data tersebut, kata keren muncul paling sering. Ciri kefimininan yang muncul pada leksikon tersebut adalah adanya pengubahan fonem. Bajingan dituturkan dengan bajirut untuk menimbulkan efek penghalusan karena bajingan berkonotasi negatif. Endel dituturkan dengan wendel untuk menimbulkan makna penyangatan, seperti halnya penambahan /u/ pada adjektiva bahasa Jawa uendel 'sangat genit'. Amazing dilafalkan dengan emeiiiiyiiiinngg yang memperlihatkan sisi kefemininan yang lembut, manja, dan ekspresif.

Interjeksi yang digunakan gender maskulin adalah cuk dan jancuk. Sementara itu, interjeksi yang digunakan gender feminin adalah buset, ya ampun, sumpah, dan bangkeeee (bangkai). Data tersebut menunjukkan bahwa gender maskulin cenderung menggunakan interjeksi yang berkonotasi negatif secara langsung, sedangkan gender feminin menggunakan bentuk yang lebih halus.

Nomina yang digunakan gender maskulin dan feminin sama-sama mengacu pada binatang anjing. Namun, leksikon tersebut diekspresikan dengan bentuk yang berbeda. Gender maskulin menuturkan asyu yang berasal dari kata asu 'anjing' sebagai bentuk penghalusan yang dilakukan hanya dengan menyisipkan satu fonem. Sementara itu, gender feminin menggunakan njirr, anjir yang merupakan penghalusan dari kata anjing. Penghalusan yang dilakukan gender feminin ini lebih lembut, yaitu dengan penghilangan dan pengubahan fonem. 


\section{b. Unsur Suprasegmental}

Dalam bahasa tulis, unsur suprasegmetal ini ditandai dengan pemanjangan bunyi, yaitu pengulangan fonem, baik vokal maupun konsonan. Gender maskulin melakukan pemanjangan bunyi pada satu data, yaitu cuuuuukk. Gender feminin melakukan pemanjangan bunyi pada kata syahduuu, kereeeeeeeeeen, omegatt, abissss, luwesss, emeiiiiyiiiinngg, njirr, bajirutt, dan bangkeeee. Penambahan fonem tersebut menunjukkan adanya sesuatu yang ditekankan dan terasa lebih ekspresif ketika dituturkan. Pengulangan konsonan menunjukkan adanya tekanan (keras lemahnya pengucapan) dan pengulangan vokal menunjukkan nada (tinggi rendahnya pengucapan). Hal itu juga tampak pada penambahan tanda baca, yaitu menuliskan dua tanda seru dan lebih dari tiga tanda titik. Data tersebut juga menunjukkan bahwa gender feminin lebih banyak menggunakan unsur suprasegmental yang mengindikasikan bahwa gender feminin lebih ekspresif daripada gender maskulin.

\section{c. Emotikon}

Penggunaan emotikon ini dibedakan berdasarkan jumlah emotikon dan jenis emotikon yang digunakan. Gender feminin cenderung menggunakan emotikon lebih banyak dengan jenis yang bervariasi daripada gender maskulin. Gender maskulin menggunakan emotikon maksimal 3 buah emotikon, sedangkan gender feminin menggunakan emotikon mencapai 9 buah dalam satu tuturan.

Gender maskulin menggunakan satu jenis emotikon, yaitu emotikon tertawa sambil menangis. Sementara itu, jenis emotikon yang digunakan gender feminin adalah emotikon love warna kuning, emotikon tertawa sampai berkeringat, emotikon muka memerah, emotikon tertarik, emotikon tertawa, emotikon memberikan ciuman, emotikon tertawa sambil menangis, emotikon tepuk tangan, emotikon jatuh cinta, emotikon memberi jempol, emotikon bahagia, dan emotikon tertawa kecil. Bentuk lain yang memiliki maksud sama dengan emotikon adalah onomatope tertawa. Gender maskulin mengungkapkannya dengan hhha dan gender feminin dengan haha serta wkwkwk

\section{KESIMPULAN}

Perbedaan bentuk respons gender maskulin dan feminin terhadap video yang diunggah akun instagram @d_kadoor dikelompokkan atas pujian, sindiran, umpatan, dan bentuk lain yang tidak teridentifikasi. Gender feminin lebih banyak menggunakan bentuk pujian (I5 penutur) dan bentuk tidak teridentifikasi ( 7 penutur). Sementara itu, gender maskulin menggunakan bentuk pujian ( 5 penutur), sindiran (I penutur), umpatan (2 penutur), dan bentuk tidak teridentifikasi (2 penutur). Data ini menunjukkan bahwa gender feminin cenderung menggunakan leksikon yang bermakna positif, sedangkan gender maskulin lebih berani dalam menggunakan kata-kata yang bermakna negatif, yaitu untuk menyindir dan mengumpat.

Perbedaan karakteristik tuturan gender maskulin dan feminin dikelompokkan berdasarkan pilihan kata, unsur suprasegmental, dan emotikon yang digunakan. Berdasarkan pilihan kata yang digunakan, gender feminin cenderung mengubah dan menambah fonem, misalnya bajirut dari bajingan dan wendel dari endel 'genit'. Gender feminin cenderung lebih banyak menggunakan unsur suprasegmental dengan melakukan pengulangan bunyi vokal dan konsonan serta penambahan tanda baca. Gender feminin cenderung menggunakan emotikon lebih banyak dengan jenis yang bervariasi daripada gender maskulin. Hal tersebut mengindikasikan bahwa gender feminin lebih ekspresif daripada gender maskulin.

\section{DAFTAR PUSTAKA}

Bohang, Fatimah Kartini. 2017. Indonesia, Pengguna Instagram Terbesar se-Asia Pasifik, (Online), (https://tekno.kompas.com/read/201 7/07/27// I 480087/indonesia-pengguna-instagramterbesar-se-asia-pasifik), diakses 29 April 2018.

Crystal, David. 1995. The Cambridge Encyclopedia of The English Language. Cambridge: Cambridge University Perss.

Kridalaksana, Harimurti. 1985. Fungsi Bahasa dan Sikap Bahasa. Ende: Nusa Indah.

Badan Bahasa Kemdikbud. Kamus Besar Bahasa Indonesia Edisi V (Versi Android), digunakan tanggal I4 Mei 2018. 
Thomas, Linda \& Wareing, Shan. 2007. Bahasa, Masyarakat, dan Kekuasaan. Yogyakarta: Pustaka Pelajar.

Putra, Rachmad Rizky. 2013. Bentuk dan Fungsi Kata Umpatan pada Komunikasi Informal di Kalangan Siswa SMA Negeri 3 Surabaya: Kajian Sosiolinguistik. Jurnal Skriptorium. I (3): 8697.

Milroy, Lesley \& Gordon Matthew. 2003. Sociolinguistics. Oxford: Blackwell Publishing.

Lakoff, Robin. 1973. Language in Woman's Place, dari artikel Language in Society, Vol. 2, No. I (Apr., 1973), pp 45-80. : Cambridge University Press.

Wijana, I Dewa Putu. 2009. Berkenalan dengan Linguistik. Yogyakarta: Pustaka Arasta \& Jurusan Sastra Indonesia FIB UGM.

Herian, Jofinno. 2017. Jangan Ngaku Anak Gaul Kalo Kamu Belum Tau Arti Emoji Berikut, (Online), (https://jalantikus.com/tips/arti-semua-emojil), diakses I4 Mei 2018.

Sudaryanto. 2015. Metode dan Aneka Teknik Analisis Bahasa: Pengantar Penelitian Wahana Kebudayaan Secara Linguistis. Yogyakarta: Sanata Dharma University Press.

Mahsun. 2012. Metode Penelitian Bahasa: Tahapan Strategi, Metode, dan Tekniknya. Jakarta: Rajawali Pers. 